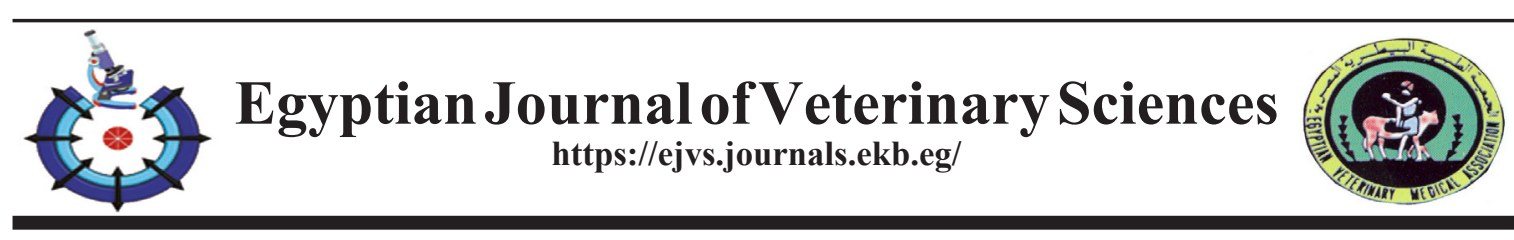

\title{
Effect of Salmonella Enterica Serovar Enteritidison Nisin Gene Expression Induced by Lactococcuslactis on Chicken Meat
}

Fahimeh Firouzbakht, Vadood Razavilar and Amirali Anvar

Department of Food Hygiene, Science and Research Branch, Islamic Azad University

Tehran, Iran.

\begin{abstract}
CONTAMINATED chicken meat is measured as one of the most significant sources of Salmonella enterica serovar Enteritidis (Ses E). Using nisin-producer Lactococcuslactis (L. lactis) is a practical approach to diminish the risk of food-borne pathogens in chicken meat. The existingsurvey was done to assess the effect of SesEon nisin gene expression induced by $L$. lactison chicken meat. Chicken meat was divided into 4 groups of L. lactis control group (BHI media inoculated with $1.5 \times 10^{8} \mathrm{CFU} / \mathrm{ml}$ L. lactis), Ses Econtrol group (BHI media inoculated with $1.5 \times 10^{5} \mathrm{CFU} / \mathrm{ml} \mathrm{Ses} \mathrm{E),} \mathrm{L.} \mathrm{lactis} \mathrm{exposure} \mathrm{group} \mathrm{(BHI} \mathrm{media} \mathrm{inoculated} \mathrm{with} 1.5 \times 10^{8}$ $\mathrm{CFU} / \mathrm{ml}$ L. lactis) and finally Ses Eexposure group (BHI media inoculated with $1.5 \times 10^{5} \mathrm{CFU} /$ $\mathrm{ml}$ Ses E). Then, $\mathrm{pH}$ and protein contents, numbers of bacteria and nisin gene expression were examined. Growth of Ses Ein the exposure group has been decreased. L. lactis inhibits from severe changes in $\mathrm{pH}$ and protein contents of chicken meat. After $4 \mathrm{~h}$ of maintenance, amount of nisin gene expression in L. lactis subsp. lactis co-culture with SesE was 1.9 times higher than L. lactis subsp. lactis mono-culture $(P=0.0008)$. After $48 \mathrm{~h}$ maintenance, amount of nisin gene expression in L. lactis subsp. lactis mono-culture was 1.1 times higher than L. lactis subsp. lactis co-culture with Ses E $(P=0.042)$. Ses Ecan cause substantial increase in the nisin gene expression and subsequent production of nisin by L. lactis subsp. lactis.
\end{abstract}

Keywords: Lactococcuslactis, Nisin, Salmonella enterica serovar enteritidis, Gene expression, Chicken meat.

\section{Introduction}

The lactic acid bacteria (LAB) are anextensive bacteriocin producers microorganisms. LAB are non-spore forming cocci, coccobacilli or rod shapes lactic acid, Gram-positive, $\mathrm{CO}_{2}$ and ethanol producing bacteria [1-3]. Bacteriocins induced by $\mathrm{LAB}$ are predominantly fascinatin gowing totheir long history of safe use. Furthermore, they are measured as Generally Regarded AsSafe (GRAS) products[1-3]. Nisin is the most renowned and GRAS lantibiotic produced by some strains of Lactococcuslactis (L. lactis) subsp. lactis [4-6]. Nisin is a bacteriocin with bactericidal and bacteriostatic effects towardabundant microorganisms[4-6]. Application of nisin-producing L. lactisbacteria as starter in food production guarantees a supplementarysecuritybenefit, sincethey can constrainconceivable contamination by potential food-borne pathogens, including Salmonella enterica ( $S$. enterica) [7, 8]. Nevertheless, the fruitfuluse of probiotic startersrely on its aptitude to nisinsynthesize in the food $[9,10]$. Moreover, construction of littleamounts of nisin in food stuffsmight be unsatisfactory to monitorspoilage bacteria and pathogens $[9,10]$. Thus, it is imperative to found anappropriate way to surge the production of nisin in food samples.

$S$. enteritica is a chief cause of food-borne diseases. Salmonella enterica serovar enteritidis (SesE) is one of the chief serovars of S. enterica subsp. enterica which can infect humans, rodents and Galliformes [11,12]. Poultry-meat and derived products are measured a chief source of

*Corresponding auther: Vadood Razavilar, E.mail: vrazavii@ut.ac.ir., Tel. +989121026502.

(Received 11/12/2019, accepted 02/03/2020)

DOI. 10.21608/ejvs.2020.20517.1142

(C)2020 National Information and Documentation Center (NIDOC) 
human infection with Salmonella. Chickens can be infected with many diverse serovars of this bacterium. Of these, SesE has boost standing. Ses Eis accountable for severe intestinal diseases and food poisoning $[11,12]$.

Microbiological surveysre commended mixed cultures as anappropriateapproach to determine novel bacteriocins or antibiotics [13, 14]. The LAB bacteriocin-producing microorganisms are existingin consort withadditionalbacteria in foods and the foremostperson of bacteriocins is reserve of the growth and survival of pathogens. Thus, the performance of bacteriocinproducing microorganisms in anattendance of virulentmicrobes is an imperativefeature $[13,14]$. Thus, an existing survey was accompanied to assess the amount of expression of nisin gene by L. lactis subsp. lactis in amalgamation with SesE in chicken meat samples.

\section{Materials and Methods}

\section{Moral deliberation}

The survey was permitted by the author's academic institute (Endorsement No910641622).

\section{Microorganisms and culture media}

The L. lactis subsp. lactis (ATCC 11454) was applied as nisin-producing. De Man Rogosa and Sharp (MRS) broth (Merck, Germany) was used for growth of L. lactis $\left(37^{\circ} \mathrm{C}\right)$. Ses E (PTCC 1709) was cultured in Brain-Herat Infusion medium (BHI, Merck, Germany) at $37^{\circ} \mathrm{C}$ [7]. Applied bacteria were prepared from the Iranian Research Organization for Science and Technology (IROST, Tehran, Iran).

\section{Study thepattern of growth of bacteria in culture media}

Nisin-positive L. lactis $\left(1.5 \times 10^{8} \mathrm{CFU} / \mathrm{mL}\right)$ was inoculated into $\mathrm{BHI}$ broth media contained $1.5 \times 10^{8} \mathrm{CFU} / \mathrm{mL}$ SesE. BHI media without any pathogenic bacteria were applied as positive control. At that time, BHI broth media were divided into 4 diverse groups of $L$. lactis control group (BHI media inoculated with $1.5 \times 10^{8}$ $\mathrm{CFU} / \mathrm{ml}$ L. lactis), Ses E control group (BHI media inoculated with $1.5 \times 10^{5} \mathrm{CFU} / \mathrm{ml}$ SesE), L. lactis exposure group (BHI media inoculated with $1.5 \times 10^{8} \mathrm{CFU} / \mathrm{ml} \mathrm{L}$. lactis) and finally and Ses E exposure group (BHI media inoculated with $1.5 \times 10^{5} \mathrm{CFU} / \mathrm{ml}$ SesE). Exposure groups contained both bacteria but $L$. lactis bacteria were only counted in L. lactis exposure group and SesE bacteria were only counted in SesE exposure group. Tubes contained SesE were reserved at $12^{\circ} \mathrm{C}$ and were microbiologically examined on days $0,3,5$, and 7 after inoculation. Counting of Ses E was done in Salmonella-Shigella (SS) Agar (Merck, Germany).

\section{Bacterial inoculation into specimens}

Anentire of 128 parts of chicken breast meat samples (about $100 \mathrm{~g}$ each) from green chicken carcasses (those who were raised without antibiotic prescription) after ward the slaughtering was obtained and individually mixed by stomacher. Ice and cool box were applied for sample's transport. Furthermore, Pulsed ultraviolet (UV)-light was used for decontamination of chicken breast meat samples. Breast meat was decorated tobits $(10$ $\mathrm{cm}^{2} \times 5 \mathrm{~mm}$ ) with approximately $10 \mathrm{~g}$ weight using a sterile knife and cutting board. At that moment, chicken breast meat samples were divided into 4 diverse groups of L. lactis control group (chicken breast meat samples inoculated with $1.5 \times 10^{8}$ $\mathrm{CFU} / \mathrm{ml}$ L. lactis), SesEcontrol group (chicken breast meat samples inoculated with $1.5 \times 10^{5}$ $\mathrm{CFU} / \mathrm{ml}$ SesE), L. lactis exposure group (chicken breast meat samples inoculated with $1.5 \times 10^{8}$ $\mathrm{CFU} / \mathrm{ml}$ L. lactis) and finally Ses Eexposure group (chicken breast meat samples inoculated with $1.5 \times 10^{5} \mathrm{CFU} / \mathrm{ml}$ SesE). Exposure groups contained both bacteria but $L$. lactis bacteria were only counted in L. lactis exposure group and Ses E bacteria were only counted in SesE exposure group. For this purpose, L. lactis culture $(0.1 \mathrm{ml}$, $\left.1.5 \times 10^{8} \mathrm{CFU} / \mathrm{ml}\right)$ with the greatest constrainaction originated from the preceding survey [7] and SesE $\left(0.1 \mathrm{ml}, 1.5 \times 10^{5} \mathrm{CFU} / \mathrm{ml}\right)$ were positioned and blowoutcarefully on the superficialshares of chicken meat specimens. All samples were reserved at $12^{\circ} \mathrm{C}$ and were microbiologically examined on days $0,3,5$, and 7 after inoculation.

\section{Microbial analysis of chicken meat samples}

Microbial counts were performed in triplicate. Sterile peptone $(0.1 \%)$ dilution was applied for sample dilution. The primary dilutions were organize dusing diluent addition to each sample $\left(10^{-1}\right)$. Obtained mixture was blended using Stomacher (Seward Medical, London, UK) for about $1 \mathrm{~min}$. Salmonella enumeration was done using XLD agar (Merck KGaA, Darmstadt, Germany) $\left(37^{\circ} \mathrm{C}\right.$ for $\left.48 \mathrm{~h}\right)$, while L. lacctis enumeration was done using MRS agar (Merck $\mathrm{KGaA}$, Darmstadt, Germany) $\left(30^{\circ} \mathrm{C}\right.$ for around $48 \mathrm{~h}$ in anaerobic circumstances). Mean values of achieved data of 2 Petri dishes were considered. 
Study the effects of L. lactis on $\mathrm{pH}$ and protein contents of chicken meat samples

Changes in the $\mathrm{pH}$ and crude protein of chicken meat samples were analyzed in order to assess the probable corruption of $L$. lactis on chicken meat. The $\mathrm{pH}$ of meat was determined using calibrated pH meter (HI 9219, Hanna Instruments; Woonsocket, RI, USA). Protein contents of chicken meat samples were analyzed using the Kjeldahl method according to the Association of Official Analytical Chemists (AOAC) [15].

\section{DNA extraction and nisinA gene detection}

Presence of the nisin gene in the L. lactis bacteria was examined using the PCR. L. lactis bacteria were sub-cultured on MRS broth (37 ${ }^{\circ} \mathrm{C}, 48 \mathrm{~h}$ ). DNA extraction kit (Thermo Fisher Scientific, Germany) was applied for DNA extraction. Technique was performed rendering to the factory instruction. Extracted DNA samples were subjected to quantification by NanoDrop device (NanoDrop, Thermo Scientific, Waltham, USA), qualification ( $2 \%$ agarose gel) and purity checking (A260/A280). PCR was performed by means of thermal cycler (Eppendorf, Germany) rendering the conveyed technique [16]. Nisin structural gene (nisin A gene) was detected in the PCR amplification of nisA primers (F: 5'TCAGGTGCATCACCACGCATTA-3' and R: 5'- $^{\prime}$ TTACGTGAATACTACAATGACAAGTTGCT $-3^{\prime}$ (115 bp)[17]. PCR was finalized using previouslymethod [17].

\section{$R N A$ extraction}

Nisin gene expression was examined using the real-time PCR. RNA purification kit (Jena Bioscience, Germany) was applied for RNA extraction rendering the factory guidelines. Extracted RNA samples were subjected to quantification by NanoDrop device (NanoDrop, Thermo Scientific, Waltham, USA) and qualification (1\% agarose gel). Extracted RNA was stored at $-80^{\circ} \mathrm{C}$ until use.

\section{Synthesis of cDNA}

Prime Script RT reagent Kit (TaKaRa Biotechnology, Japan) was applied for synthesis of cDNA from $500 \mathrm{ng}$ of extracted RNA.

\section{Nisin gene expression using the real-time PCR}

Effect of SesE on nisin gene expression induced by $L$. lactis bacteria was examined using the RT-PCR. RT-PCR reaction was performed by means of the real-time PCR device (Qiagen, Germany). Table 1 illustrates list of primers of the RT-PCR[18]. The 16S rRNA gene was used as house kipping gene. Procedures were performed rendering beforehand techniques $[7,18,19]$. Primer applied for nisin A gene amplification was designed by means of the Light Cycler probe design software (v1.0; Roche Applied Science, Mannheim, Germany) and synthesized by Eurogentec (Seraing, Belgium). Primer's validity was confirmed by means of the Basic Local Alignment Search Tool (BLAST) of the National Center for Biotechnology Information. NCBI-primer blast facility was applied to check the specificity of primers. The real-time PCR reaction was performed in $10 \mu \mathrm{l}$ volume including SYBR Green PCR Mastermix $(5 \mu$ l, Thermo Fisher Scientific, Germany), forward and reverse primers (100 nM of each), cDNA (200 ng) and water. The amplification was included $95{ }^{\circ} \mathrm{C}$ for $15 \mathrm{~min}$, followed by 40 cycles of $95^{\circ} \mathrm{C}$ for $45 \mathrm{~s}$ and at $50{ }^{\circ} \mathrm{C}$ for $45 \mathrm{~s}$.

\section{Numerical examination}

Tests were performed in triplicates. Data were examined by the SPSS 21.0 (Chicago, USA). Two-way ANOVA and additionally Tukey's tests were perfumed. P level of $\leq 0.05$ was measured as level of meaning.

\section{Results}

Table 2 demonstrates the counting L. lactis and SesE on chicken meat during the maintenance period in culture media. Numbers of all tested bacteria in all examined groups have been meaning fully amplified up to day 3 of maintenance period $(P \leq 0.05)$ with the exception of the L. lactis control group $(P>0.05)$. Growth of SesE in the exposure group on days 3 to 7 has been meaning fully reduced $(P \leq 0.05)$.

Table 3 displays the numbers of $L$. lactis and SesE on chicken meat throughout the maintenance period. Numbers of all tested bacteria in all examined groups have been meaning fully amplified throughout the maintenance period $(P$ $\leq 0.05$ ). Growth of SesE in the exposure group on days 3 to 7 has been meaning fully reduced $(P \leq 0.05)$.

Table 4 characterizes the $\mathrm{pH}$ changes of chicken meat samples inoculated with $L$. lactis during the maintenance period. The mean content of $\mathrm{pH}$ in chicken meat samples in L. lactis control group was $5.8 \pm 0.2$ at the beginning of the maintenance period. The mean content of $\mathrm{pH}$ of chicken meat samples in L. lactis control group has been numerically reduced $(P<0.05)$. The mean content of $\mathrm{pH}$ in chicken meat samples in $L$. 
lactis control group was $5.0 \pm 0.1$ at the end of the maintenance period. There were no numerically variance for content of $\mathrm{pH}$ amid $5^{\text {th }}$ and $7^{\text {th }}$ days of maintenance in the L. lactis control group $(P>0.05)$. The mean content of $\mathrm{pH}$ in raw chicken meat samples was $5.9 \pm 0.1$ at the beginning of the maintenance period. The mean content of $\mathrm{pH}$ of raw chicken meat samples has been numerically amplified $(P<0.05)$. The mean content of $\mathrm{pH}$ in raw chicken meat samples was $6.9 \pm 0.2$ at the end of the maintenance period. Numerical noteworthyvariances were gotten for the mean content of $\mathrm{pH}$ amid raw chicken meat samples and L. lactis control group in $3^{\text {th }}, 5^{\text {th }}$ and $7^{\text {th }}$ days of maintenance $(P<0.05)$.

TABLE 1. List of primers used for study the nisin gene expression by the RT-PCR.

\begin{tabular}{cclc}
\hline Target gene & \multicolumn{1}{c}{ Product } & \multicolumn{1}{c}{ Primer sequence $\left(\mathbf{5}^{\prime} \mathbf{- 3}\right.$ ) } & Reference \\
\hline \multirow{2}{*}{$16 \mathrm{~S} r$ RNA } & 16S ribosomal RNA & F: GCTCACCAAGGCGATGATACATA & 17 \\
& & R: ACCAACGTTCTTCTCTACCAACA & \\
\multirow{2}{*}{ Nisin A } & Nisin Structural Gene & F: TTCGAAGAAAGATTCAGGTGC & This study \\
& & R: TTGATTTGGTATTTGCTACGTG & \\
\hline
\end{tabular}

TABLE 2. Counting of $L$. lactis and SesE on chicken meat during the maintenance period in culture media.

\begin{tabular}{|c|c|c|c|c|c|}
\hline \multirow{2}{*}{ Groups } & \multirow{2}{*}{ Treatments } & \multicolumn{4}{|c|}{ Counts $(\mathrm{CFU} / \mathrm{ml})$ in days of maintenance } \\
\hline & & $\mathbf{0}$ & 3 & 5 & 7 \\
\hline 1 & SesE control group & $1.40 \times 10^{5} \mathrm{Bb}^{*}$ & $7.00 \times 10^{8} \mathrm{Aa}$ & $1.00 \times 10^{10} \mathrm{Bb}$ & $6.60 \times 10^{11} \mathrm{Aa}$ \\
\hline 2 & SesE exposure group & $1.90 \times 10^{5} \mathrm{Ab}$ & $3.50 \times 10^{8} \mathrm{Ca}$ & $1.00 \times 10^{10} \mathrm{Bb}$ & $1.00 \times 10^{11} \mathrm{Bb}$ \\
\hline 3 & L. lactis control group & $1.40 \times 10^{8} \mathrm{Ba}$ & $1.20 \times 10^{9} \mathrm{Da}$ & $1.60 \times 10^{9} \mathrm{Aa}$ & $1.20 \times 10^{10} \mathrm{Ba}$ \\
\hline 4 & $\begin{array}{l}\text { L. lactis exposure } \\
\text { group }\end{array}$ & $1.30 \times 10^{8} \mathrm{Bb}$ & $5.00 \times 10^{8} \mathrm{Ba}$ & $1.20 \times 10^{9} \mathrm{Bb}$ & $1.10 \times 10^{10} \mathrm{Bb}$ \\
\hline
\end{tabular}

*Unlike capital letters in each column illustrate numerical noteworthy variances about $\mathrm{P}<0.05$.

Unlike small letters in each row illustrate numerical noteworthy variances about $\mathrm{P}<0.05$.

TABLE 3. Counting of $L$. lactis and Ses $\mathbf{E}$ on chicken meat during the maintenance period in chicken meat.

\begin{tabular}{clcccc}
\hline \multirow{2}{*}{ Groups } & \multicolumn{1}{c}{ Treatments } & \multicolumn{4}{c}{ Counts $(\mathbf{C F U} / \mathbf{m l})$ in days of maintenance } \\
\cline { 3 - 6 } & & $\mathbf{0}$ & $\mathbf{3}$ & $\mathbf{5}$ & $\mathbf{7}$ \\
\hline 1 & SesE control group & $2.80 \times 10^{5} \mathrm{Cc}^{*}$ & $4.30 \times 10^{7} \mathrm{Bb}$ & $1.10 \times 10^{10} \mathrm{Aa}$ & $5.70 \times 10^{11} \mathrm{Aa}$ \\
2 & SesE exposure group & $1.00 \times 10^{5} \mathrm{Cc}$ & $5.00 \times 10^{6} \mathrm{Cb}$ & $9.40 \times 10^{6} \mathrm{Bb}$ & $3.00 \times 10^{7} \mathrm{Ba}$ \\
3 & L. lactis control group & $9.00 \times 10^{7} \mathrm{Bd}$ & $9.60 \times 10^{9} \mathrm{Ac}$ & $2.60 \times 10^{10} \mathrm{Ab}$ & $6.00 \times 10^{11} \mathrm{Aa}$ \\
4 & L. lactis exposure group & $2.60 \times 10^{8} \mathrm{Ac}$ & $1.00 \times 10^{10} \mathrm{Ab}$ & $1.50 \times 10^{10} \mathrm{Ab}$ & $1.70 \times 10^{11} \mathrm{Aa}$ \\
\hline
\end{tabular}

${ }^{*}$ Dissimilar capital letters in each column illustrate numerical noteworthy variances about $\mathrm{P}<0.05$.

Dissimilar small letters in each row illustrate numerical noteworthy variances about $\mathrm{P}<0.05$.

TABLE 4. pH changes of chicken meat samples inoculated with L. lactis during the maintenance period.

\begin{tabular}{lcccc}
\hline Treatments & \multicolumn{4}{c}{ pH in days of maintenance } \\
\cline { 2 - 5 } & $\mathbf{0}$ & $\mathbf{3}$ & $\mathbf{5}$ & $\mathbf{7}$ \\
\hline L. lactis control group & $5.8 \pm 0.2 \mathrm{Aa}^{*}$ & $5.4 \pm 0.1 \mathrm{Ab}$ & $5.1 \pm 0.2 \mathrm{Ac}$ & $5.0 \pm 0.1 \mathrm{Ac}$ \\
Raw meat samples & $5.9 \pm 0.1 \mathrm{Ac}$ & $6.1 \pm 0.1 \mathrm{Bc}$ & $6.5 \pm 0.2 \mathrm{Bb}$ & $6.9 \pm 0.2 \mathrm{Ba}$ \\
\hline
\end{tabular}

*Dissimilar capital letters in each column illustrate numerical noteworthy variances about $\mathrm{P}<0.05$.

Dissimilar small letters in each row illustrate numerical noteworthy variances about $\mathrm{P}<0.05$. 
Table 5 characterizes the protein contents of chicken meat samples inoculated with L. lactis during the maintenance period according to Kjeldahl method. The mean content of protein in chicken meat samples in L. lactis control group was $17.90 \pm 1.25$ at the beginning of the maintenance period. The mean content of protein of chicken meat samples in L. lactis control group has been decreased $(P>0.05)$. The mean content of protein in chicken meat samples in L. lactis control group was $17.02 \pm 1.36$ at the end of the maintenance period. The mean content of protein in raw chicken meat samples was $17.93 \pm 1.05$ at the beginning of the maintenance period. The mean content of protein of raw chicken meat samples has been numerical decreased $(P<0.05)$. The mean content of protein in raw chicken meat samples was $14.29 \pm 1.25$ at the end of the maintenance period. Numerical noteworthy variances were gotten for the mean content of protein amid raw chicken meat samples and L. lactis control group in $3^{\text {th }}, 5^{\text {th }}$ and $7^{\text {th }}$ days of maintenance $(P<0.05)$.
Presence of the nisin $A$ gene in the L. lactis bacteria was approved by means of conventional PCR reaction. Figure 1 characterizes the consequences of the PCR visualization of nisin A gene using the PCR method. We found that all strains had nisin A gene.

Accuracy of RNA extraction and quality of extracted RNA were assessed using the gel electrophoresis. Totally, presence of $16 \mathrm{~S}, 18 \mathrm{~S}$ and $28 \operatorname{SrRNA}$ genes were analyzed in the gel electrophoresis.

Figure 2 characterizes the relative gene expression examination of nisin in L. lactis subsp. lactiscombination with $S e$ S in chicken meat samples $4 \mathrm{~h}$ after the beginning of maintenance period at $12{ }^{\circ} \mathrm{C}$. Results exhibited that the amount of nisin gene expression in L. lactis subsp. lactis co-culture with Ses E (L. lactis exposure group) was 1.9 times higher than L. lactis subsp. lactis mono-culture (L. lactis control group). Numerical noteworthy variances were gotten for the nisin

TABLE 5. Protein changes of chicken meat samples inoculated with L. lactis during the maintenance period.

\begin{tabular}{lcccc}
\hline \multirow{2}{*}{ Treatments } & \multicolumn{4}{c}{ Protein $(\boldsymbol{\%})$ in days of maintenance } \\
\cline { 2 - 5 } & $\mathbf{0}$ & $\mathbf{3}$ & $\mathbf{5}$ & $\mathbf{7}$ \\
\hline L. lactis control group & $17.90 \pm 1.25 \mathrm{Aa}^{*}$ & $17.65 \pm 1.41 \mathrm{Aa}$ & $17.20 \pm 1.55 \mathrm{Aa}$ & $17.02 \pm 1.36 \mathrm{Aa}$ \\
Raw meat samples & $17.93 \pm 1.05 \mathrm{Aa}$ & $16.89 \pm 1.72 \mathrm{Bb}$ & $15.41 \pm 1.19 \mathrm{Bc}$ & $14.29 \pm 1.25 \mathrm{Bd}$ \\
\hline
\end{tabular}

${ }^{*}$ Dissimilar capital letters in each column illustrate numerical noteworthy variances about $\mathrm{P}<0.05$.

Dissimilar small letters in each row illustrate numerical noteworthy variances about $\mathrm{P}<0.05$.

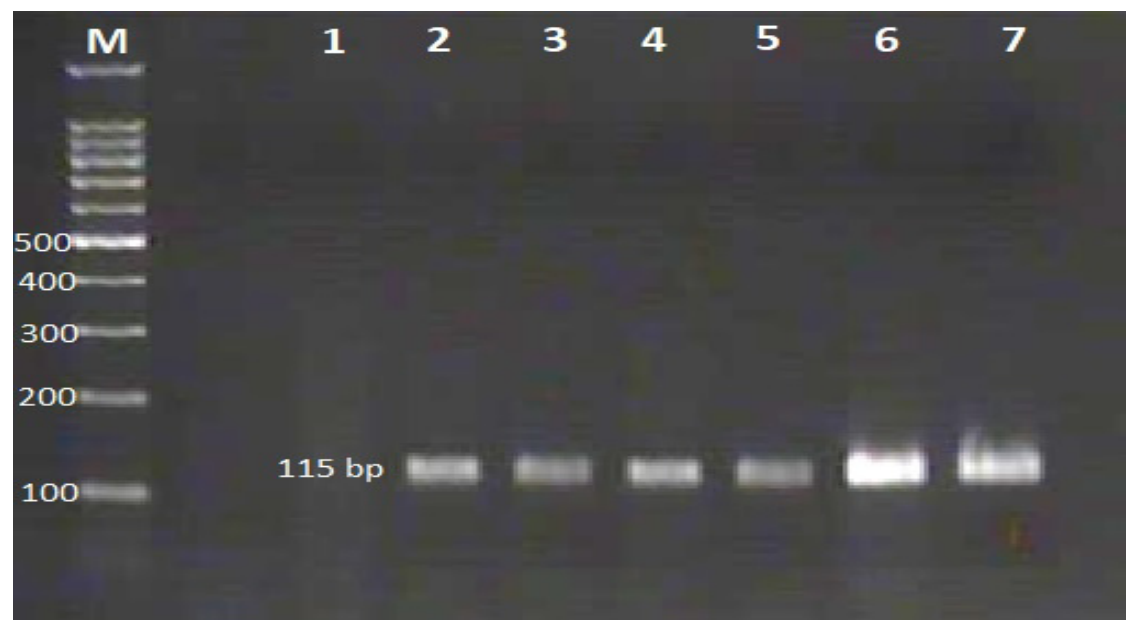

Fig. 1. Results of the gel electrophoresis of the nisin A gene in the L. lactis strains. M: 100 bp ladder (Thermo Fisher Scientific, St. Leon-Rot, Germany), lane 1: Negative control (PCR grade water (Thermo Fisher Scientific, St. Leon-Rot, Germany)), lanes 2-6: positive samples for the nisin A gene in the L. lactis (115 bp) and lane 7: Positive control (L. lactis ATCC 11454). 
gene expression amid $L$. lactis exposure group and $L$. lactis control group $(P=0.0008)$.

Figure 3 characterizes the relative gene expression examination of nisin in L. lactis subsp. lactis combination with SesE in chicken meat samples after $48 \mathrm{~h}$ of maintenance at 12 ${ }^{\circ} \mathrm{C}$. Results showed that the amount of nisin gene expression in L. lactis subsp. lactis mono-culture (L. lactis control group) was 1.1 times higher than L. lactis subsp. lactiscombination with SesE ( $L$. lactis exposure group). This finding exhibited decrease in the nisin gene expression in L. lactis subsp. lactiscombination with SesE after 48 h of maintenance at $12{ }^{\circ} \mathrm{C}$. Nevertheless, there were no numerical noteworthy variances for the nisin

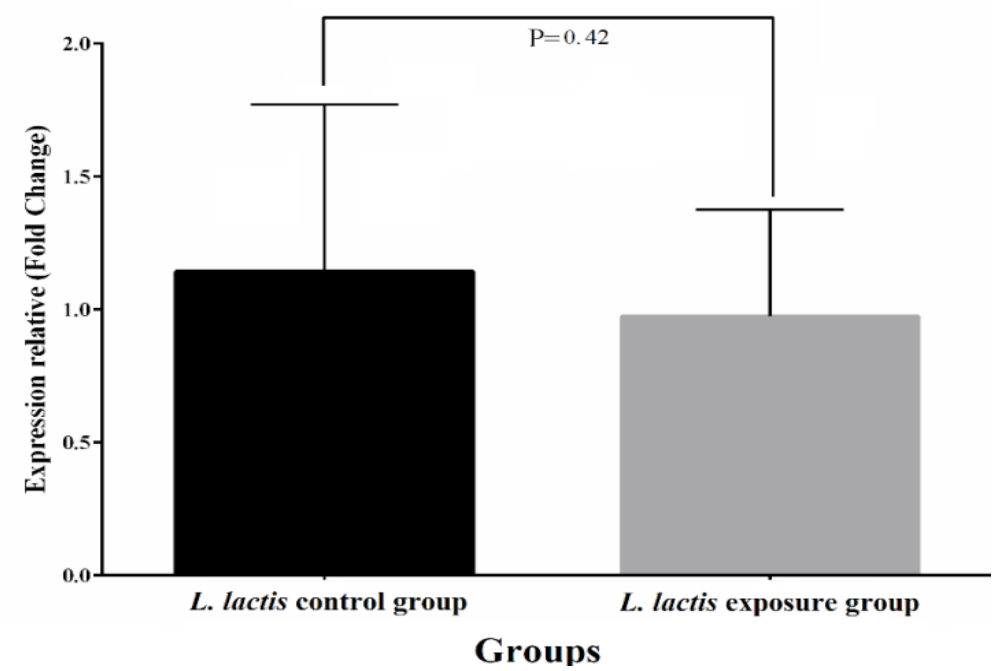

Fig. 2. Relative gene expression analysis of nisin in L. lactis subsp. lactis co-culture with SesE in chicken meat samples $4 \mathrm{~h}$ after the beginning of maintenance period at $12^{\circ} \mathrm{C}$. Changes in gene expressions were measured using quantitative reverse transcription PCR (RT-qPCR).

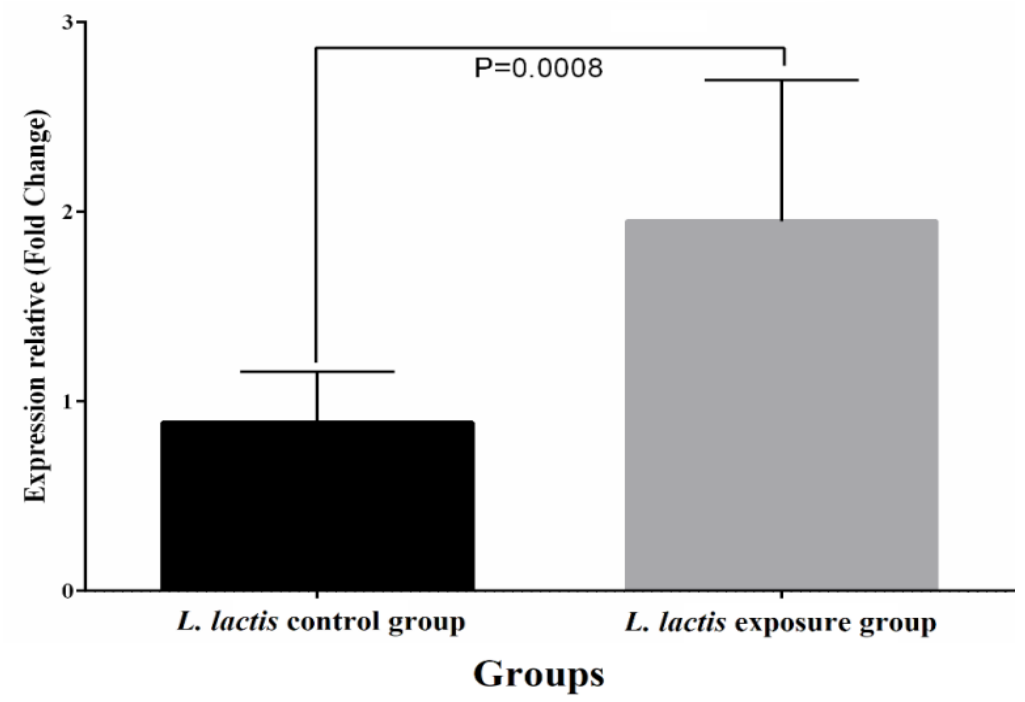

Fig. 3. Relative gene expression analysis of nisin in L. lactis subsp. lactis co-culture with SesE in chicken meat samples after $48 \mathrm{~h}$ of maintenance at $12^{\circ} \mathrm{C}$. Changes in gene expressions were measured using quantitative reverse transcription PCR (RT-qPCR). 
gene expression amid L. lactis exposure group and L. lactis control group $(P=0.42)$.

\section{Discussion}

An existing survey was done to assess the role of SesE on nisin gene expression induced by $L$. lactison chicken meat samples. Apparently, this is an initial report of the study of effect of the SesE on L. lactisnis in gene expression on chicken meat samples. Findings described that L. lactis caused significant decrease in the numbers of SesE growth on chicken meat. Additionally, co-culture of L. lactis with SesE caused significant increase in the nisin gene expression $4 \mathrm{~h}$ after the beginning of maintenance period of chicken meat samples at $12^{\circ} \mathrm{C}$ which was interesting. Microbiological and food related investigations revealed that changes in the temperature, osmotic pressure and acidity are the greatest mutualtensioncircumstances originated in food stuffmanufacture and to which L. lactis nisin gene expressions subjected [2022]. Additionally, inoculation and growth of certain bacteria in media and/or food systems in association with L. lactis is introduced as a probable factor increasing nisin gene expression [20-22].

Nisin mainly constrains growth of Grampositive bacteria by pores formation in their membrane. Clearly, nisin is not operativetoward Gram-negative bacteria, since it cannot transfer through their cell membrane owing to its large molecular size [23]. However, our findings revealed that co-inoculation of nisin producer $L$. lactis with SesE decrease the numbers of viable Salmonella in chicken meat samples. There were two probable reasons for this finding. At first, L. lactis caused significant decrease in the $\mathrm{pH}$ content of chicken meat samples which make the conditions hard for growth of SesE. At second, increase in the expression of nisin gene caused by presence of $S$ SesE and subsequently higher production of nisin gene make the conditions hard for growth and survival of SesE. Owing to presence of Gram-negative and nisin-resistant microorganisms, nisin may not be adequate to avoid meat spoilage. In keeping with this, decrease in the levels of $\mathrm{pH}$ and proteins (which may deliberate as significant stresses for nisin gene expression) and increase in the nisin gene expression induced by presence of Salmonella may be effective protocols caused significant increase in the levels of nisin. Thus, higher concentrations of nisin caused decrease in the numbers of SesE.
We also found L. lactis inhibits from protein destructions in the chicken meat samples (in comparison with raw chicken meat samples). Therefore, using from $L$. lactis may inhibit from the reduction in nutritional qualities of chicken meat samples in the maintenance period. Additionally, decrease in the $\mathrm{pH}$ contents of chicken meat samples induced by L. lactis is the main factor inhibit from the growth of pathogenic bacteria and protein degradation. It has been conveyed that the flinch of the logarithmic development of $L$. lactis subsp. lactis was detectedamid 9 and $15 \mathrm{~h}$ at 12 ${ }^{\circ} \mathrm{C}$. At these intervals, the uppermost decrease in $\mathrm{pH}$ of the chicken meat was also detected. The stationary phase at $12{ }^{\circ} \mathrm{C}$ started amid 18 and $24 \mathrm{~h}$ [19]. It has also been conveyed that nisin production was much higher in logarithmic phase of growth of L. lactis subsplactis [24]. Additionally, development of LAB in meat can lead to the little hydrolysis of its proteins (which was also seen in the present study) and formation of peptides with antimicrobial characteristics [25]. Additionally, intricate matrices, including meat and milk, mightdelay with the bactericidal dimensions of bacteriocins, owing tocommunications with lipids and proteins and proteolysis [26]. Therefore, it is not surprising that L. lactis caused sever decrease in the numbers of SesE especially in its logarithmic phase of growth.

Amounts of gene expression in the L. lactis exposure group was higher than L. lactis control group $4 \mathrm{~h}$ after the beginning of maintenance period at $12{ }^{\circ} \mathrm{C}$. Diversely, amounts of gene expression in the L. lactis control group was higher than $L$. lactis exposure group after $48 \mathrm{~h}$ of maintenance at $12{ }^{\circ} \mathrm{C}$. The chiefmotive for this discovery is the fact that $L$. lactis had the highest nisin secretion at the logarithmic phase of growth. While, decrease in the growth of L. lactis (after $48 \mathrm{~h}$ ) caused significant decrease in the nisin gene expression. The production of nisin is hang on density of cell and is monitored at the levels of manufacturing of peptides $[27,28]$. In the motionlessstage of growth of L. lactis in combination, it wasn'ttalented to promptnisin gene over and above in modest cultures owing toinferior cell density of $L$. lactis in opposition with SesE. Nevertheless, production of nisin in aninitial log stage of growth of $L$. lactis in combination was much developed than modest cultures. An existing divergencemight be associated with inferioraccessibility of supplementary constituents compulsory for 
predecessor alteration of nisin, transportation and processing in mono-cultures. Numerous genes are donated for establishednisin production which are measured by supervisorys equences of DNA, positioned upstream of anencoding area. Effects of these genes after $12 \mathrm{~h}$ of inoculation of L. lactis in food samples have been decreased [27, 28]. Unfortunately, rare studies have been conducted about the effects of pathogenic bacteria on nisin gene expression of L. lactis. Abdollahi et al. (2018) [7] conveyed that the upper most quantities of nisin and its level of gene dictation were perceived in humble and combined cultures afterward $16 \mathrm{~h}$ of cultivation, simultaneous with the culmination of growth of L. lactisin described stage. They also showed that the L. lactis induced higher concentrations of nisin when it was in contact with pathogenic bacteria and especially Ses E and Listeria monocytogenes which were similar to our findings. Totally, role of food-borne pathogens in occurrence of food-borne diseases has been measured in Iran and diverse surveys have been conducted in this field [29-39].

\section{Conclusion}

In deduction, we identified a significant effects of L. lactis subsp. lactis on growth and proliferation of SesE in chicken meat samples. Additionally, the effect of SesE on nisin gene expression was observed. An existing survey is an initial report of assess the effect of SesE on nisin gene expression induced by $L$. lactison chicken meat samples. $L$. lactis caused significant decrease in the numbers of SesE in chicken meat. Furthermore, L. lactis caused significant decrease in $\mathrm{pH}$ levels of chicken meat samples. It is also inhibits from protein destruction through the maintenance period. Amount of nisin gene expression after $4 \mathrm{~h}$ from the beginning of maintenance period at $12^{\circ} \mathrm{C}$ in L. lactis subsp. lactis co-culture with SesE was 1.9 times higher than L. lactis subsp. lactis mono-culture. Reversely, amount of nisin gene expression after $48 \mathrm{~h}$ of maintenance at $12^{\circ} \mathrm{C}$ in L. lactis subsp. lactis mono-culture was 1.1 times higher than L. lactis subsp. lactis co-culture with Ses E. Therefore, presence of Ses Eis maybe the positive stress on nisin gene expression and subsequent production of nisin by $L$. lactis subsp. lactis especially $4 \mathrm{~h}$ after the beginning of maintenance period at $12{ }^{\circ} \mathrm{C}$ in chicken meat samples. The present investigation has some limitations such as failure to study the role of other pathogenic bacteria on nisin gene expression induced by L. lactis and lack of multifactorial survey on effects of different $\mathrm{pH}$ levels and temperature on nisin gene expression induced by L. lactis. However, the results of the present investigation may have some practical applications in food industry such as increase in production of natural nisin induced by L. lactis using the SesE co-culture, decrease the load of SesE in chicken meat using the nisin induced by addition of $L$. lactis and finally improve the sensory properties of chicken meat samples kept at $12{ }^{\circ} \mathrm{C}$ by nisin induced by L. lactis.

\section{Acknowledgment:}

The authors would like to thank Veterinary Organization of the Tehran province, Tehran, Iran.

Conflict of interest:

The authors declared that no conflict of interest.

Funding statement: Self-funding.

\section{References}

1. Zacharof, M. and Lovitt, R., Bacteriocins produced by lactic acid bacteria a review article. $A P C B E E$ Procedia., 2, 50-56 (2012).

2. Rodney, H., Perez, Takeshi, Zendo and Kenji Sonomoto, Novel bacteriocins from lactic acid bacteria (LAB): various structures and applications. Microbial Cell factories, Bio. Med. Central; 13(Suppl.1), S3 (2014). http://www. microbialcellfactories.com/content/13/S1/S3

3. De Vuyst, L. and Leroy, F., Bacteriocins from lactic acid bacteria: production, purification, and food applications. J. Molecul. Microb. Biotech., 13(4),194-199 (2007).

4. Dussault, D., Vu, K.D. and Lacroix, M., Enhancement of Nisin Production by Lactococcus lactis subsp. lactis. Probiotic. Antimicrob. Protein, 8(3), 170-175 (2016).

5. de Arauz, L.J., Jozala, A.F., Pinheiro, G.S., Mazzola, P.G., Júnior, A.P. Vessoni Penna, T.C., Nisin expression production from Lactococcus lactis in milk whey medium. J. Chem. Techno. Biotech., 83(3),325-328 (2008).

6. Song, A.A.L., In, L.L., Lim, S.H.E. and Rahim, R.A., A review on Lactococcus lactis: from food to factory. Microb. Cell. Factor, 16(1),Article number:55, pages 1-15(2017). DOI 10.1186/ s12934-017-0669-x 
7. Abdollahi, S., Ghahremani, M.H., Setayesh, N. and Samadi, N., Listeria monocytogenes and Salmonella enterica affect the expression of nisin gene and its production by Lactococcus lactis. Microb.Pathogen., 123,28-35 (2018).

8. Singh, A.P., Prabha, V. and Rishi, P., Value addition in the efficacy of conventional antibiotics by nisin against Salmonella. PloS.One, 8(10),e76844 (2013).

9. Perin, L.M., Dal Bello, B., Belviso, S., Zeppa, G., de Carvalho, A.F., Cocolin, L. and Nero, L.A., Microbiota of Minas cheese as influenced by the nisin producer Lactococcus lactis subsp. lactis GLc05. Inter. J. Food. Microbiol., 214,159-167 (2015).

10. Wesche, A.M., Gurtler, J.B., Marks, B.P. and Ryser, E.T., Stress, sublethal injury, resuscitation, and virulence of bacterial foodborne pathogens. $J$. Food. Protect., 72(5),1121-1138 (2009).

11. Afshari, A., Baratpour, A., Khanzade, S. and Jamshidi, A., Salmonella Enteritidis and Salmonella Typhimorium identification in poultry carcasses. Iranian. J. Microb., 10(1),45-50 (2018).

12. Yin, M., Yang, B., Wu, Y., Wang, L., Wu, H., Zhang, T. and Tuohetaribayi, G., Prevalence and characterization of Salmonella enterica serovar in retail meats in market place in Uighur, Xinjiang, China. Food Control, 64,165-172 (2016).

13. Maldonado-Barragán, A., Caballero-Guerrero, B., Martín, V., Ruiz-Barba, J.L. Rodríguez, J.M., Purification and genetic characterization of gassericin E, a novel co-culture inducible bacteriocin from Lactobacillus gasseri EV1461 isolated from the vagina of a healthy woman. BMC. Microbiol., 16(1),1-13 (2016).

14. Pettit, R.K., Mixed fermentation for natural product drug discovery. App. Microb. Biotech., 83(1),19-25 (2009).

15. Williams, S., Official Methods of Analysis of the Association of Analytical Chemists. Association of Analytical Chemists, $14^{\text {th }}$ ed (1984).

16. Ho, S.-A., Hoyle, J., Lewis, F., Secker, A., Cross, D., Mapstone, N., Dixon, M., Wyatt, J., Tompkins, D. and Taylor, G., Direct polymerase chain reaction test for detection of Helicobacter pylori in humans and animals. J. Clin. Microbiol., 29(11),2543-2549 (1991).
17. Trmčić, A., Monnet, C., Rogelj, I. and Matijašić, B.B., Expression of nisin genes in cheese-a quantitative real-time polymerase chain reaction approach. J. Dairy. Sci., 94(1),77-85 (2011).

18. Monnet, C., Ulvé, V., Sarthou, A.-S. and Irlinger, F., Extraction of RNA from cheese without prior separation of microbial cells. App. Env. Microbiol., 74(18),5724-5730 (2008).

19. Miranda, R.O., Campos-Galvão, M.E.M. and Nero, L.A., Expression of genes associated with stress conditions by Listeria monocytogenes in interaction with nisin producer Lactococcus lactis. Food. Res. Int., 105, 897-904 (2018).

20. Ulve, V., Monnet, C., Valence, F., Fauquant, J., Falentin, H. and Lortal, S., RNA extraction from cheese for analysis of in situ gene expression of Lactococcus lactis. J. App. Microb., 105(5),13271333 (2008).

21. Mierau, I. and Kleerebezem, M., 10 years of the nisin-controlled gene expression system (NICE) in Lactococcus lactis. App. Microb. Biotech., 68(6),705-717 (2005).

22. Zhou, X.X., Li, W.F., Ma, G.X. and Pan, Y.J., The nisin-controlled gene expression system: construction, application and improvements. Biotech. Adv., 24(3),285-295 (2006).

23. Prince, A., Sandhu, P., Ror, P., Dash, E., Sharma, S., Arakha, M., Jha, S., Akhter, Y. and Saleem, M., Lipid-II independent antimicrobial mechanism of nisin depends on its crowding and degree of oligomerization. Sci.Report.,6, Article number : 37908, pp. 1-14 (2016). doi: 10.1038/srep37908.

24. Furtado, N.D., Todorov, S.D., Landgraf, M., Destro, M.T. and Franco, B.D.G.M., Bacteriocinogenic Lactococcus lactis subsp. lactisDF04Mi isolated from goat milk: Characterization of the bacteriocin. Brazilian. J. Microb., 45(4),1541-1550 (2014).

25. Benkerroum, N., Antimicrobial peptides generated from milk proteins: a survey and prospects for application in the food industry. A review. Int. J. Dairy. Techno., 63(3),320-338 (2010).

26. Hernandez, D., Cardell, E. and Zarate, V., Antimicrobial activity of lactic acid bacteria isolated from Tenerife cheese: initial characterization of plantaricin TF711, a bacteriocin-like substance produced by Lactobacillus plantarum TF711. J. App. Microb., 99(1),77-84 (2005). 
27. Kuipers, O.P., Beerthuyzen, M.M., de Ruyter, P.G., Luesink, E.J. and de Vos, W.M., Autoregulation of nisin biosynthesis in Lactococcus lactis by signal transduction. J. Bio. Chem., 270(45),27299-27304 (1995).

28. De Ruyter, P., Kuipers, O.P., Beerthuyzen, M.M., van Alen-Boerrigter, I. and de Vos, W.M., Functional analysis of promoters in the nisin gene cluster of Lactococcus lactis. J. Bacteriol., 178(12),3434-3439 (1996).

29. Dehkordi, F., Parsaei, P., Saberian, S., Moshkelani, S., Hajshafiei, P., Hosseini, S., Babaei, M. and Ghorbani, M., Prevalence study of Theileria annulata by comparison of four diagnostic techniques in southwest Iran. Bulgar. J. Vet. Med., 15,123-130 (2012).

30. Hemmatinezhad, B., Khamesipour, F., Mohammadi, M., Safarpoor Dehkordi, F. and Mashak, Z., Microbiological Investigation of O-Serogroups, Virulence Factors and Antimicrobial Resistance Properties of Shiga Toxin-Producing Escherichia Coli Isolated from Ostrich, Turkey and Quail Meats. J. Food. Safe., 35(4),491-500 (2015).

31. Madahi, H., Rostami, F., Rahimi, E. and Dehkordi, F.S., Prevalence of enterotoxigenic Staphylococcus aureus isolated from chicken nugget in Iran. Jundishapur. J. Microbiol., 7(8), e10237(2014). doi: 10.5812/jjm.10237.

32. Safarpoor Dehkordi, F., Barati, S., Momtaz, H., Hosseini Ahari, S.N. and Nejat Dehkordi, S., Comparison of shedding, and antibiotic resistance properties of listeria monocytogenes isolated from milk, feces, urine, and vaginal secretion of bovine, ovine, caprine, buffalo, and camel species in Iran. Jundishapur. J. Microbiol., 6(3),284-294 (2013).

33. Momtaz, H., Davood Rahimian, M. and Safarpoor Dehkordi, F., Identification and characterization of Yersinia enterocolitica isolated from raw chicken meat based on molecular and biological techniques. J. App. Poultry. Res., 22(1),137-145 (2013).

34. Ghorbani, F., Gheisari, E. and Dehkordi, F.S., Genotyping of vacA alleles of Helicobacter pylori strains recovered from some Iranian food items. Tropical Journal of Pharmaceutical Research, 15(8), 1631-1636 (2016).
35. Rahimi, E., Sepehri, S., Dehkordi, F.S., Shaygan, S. and Momtaz, H., Prevalence of Yersinia species in traditional and commercial dairy products in Isfahan Province, Iran. Jundishapur. J. Microb.,7(4) , e9249(2014).doi: 10.5812/jjm.9249

36. Safarpoor Dehkordi, F., Khamesipour, F. and Momeni, M., Brucella abortus and Brucella melitensis in Iranian bovine and buffalo semen samples: The first clinical trial on seasonal, Senile and geographical distribution using culture, Conventional and real-time polymerase chain reaction assays. Kafkas. Üni. Vet. Fakült. Derg., 20(6),821-828 (2014)

37. Safarpoor Dehkordi, F., Haghighi, N., Momtaz, H., Rafsanjani, M.S. and Momeni, M., Conventional vs real-time PCR for detection of bovine herpes virus type 1 in aborted bovine, buffalo and camel foetuses. Bulgarian. J. Vet. Med., 16(2),102-111 (2013).

38. Rahimi, E., Yazdanpour, S. and Dehkordi, F., Detection of Toxoplasma gondii antibodies in various poultry meat samples using enzyme linked immuno sorbent assay and its confirmation by polymerase chain reaction. J. Pure. Appl. Microbio., 8(1),421-427 (2014).

39. Safarpoor Dehkordi, F., Valizadeh, Y., Birgani, T. Dehkordi, K., Prevalence study of Brucella melitensis and Brucella abortus in cow's milk using dot enzyme linked immuno sorbent assay and duplex polymerase chain reaction. J. Pure. Appl. Microbiol., 8,1065-1069 (2014). 